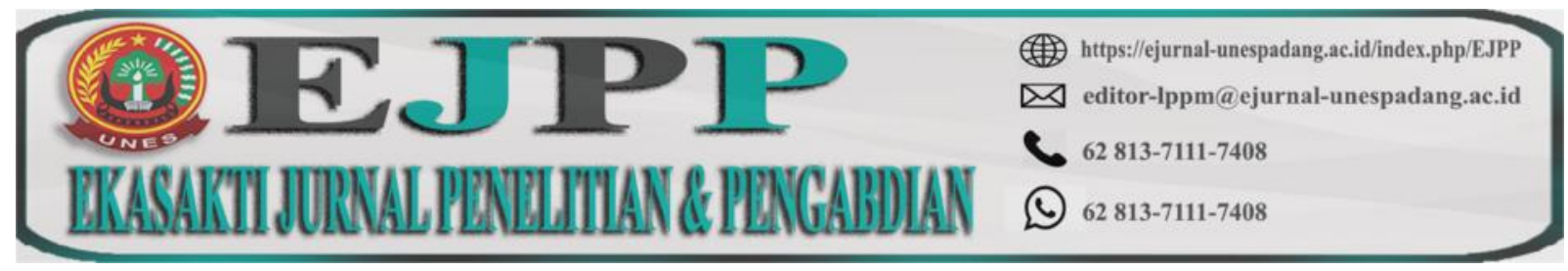

DOI: https://doi.org/10.31933/ejpp.v1i1

Received: 02/10/2020, Revised: 25/10/2020, Publish: 22/11/2020

\title{
PERLINDUNGAN HUKUM TERHADAP KORBAN TINDAK PIDANA PERDAGANGAN ORANG STUDI ATAS KELEMBAGAAN, RUANG LINGKUP SERTA KEBIJAKAN
}

\author{
Julaiddin $^{1}$ dan J. Sam. Miekhel ${ }^{2}$ \\ ${ }^{1)}$ Fakultas Hukum Universitas Ekasakti. \\ Email: julaiddinmr@gmail.com \\ ${ }^{2)}$ Program Studi Magister Ilmu Hukum Fakultas Hukum Universitas Ekasakti. \\ Email: jsammiekhel29@gmail.com
}

\begin{abstract}
ABSTRAK
Pada tingkat dunia, perdagangan orang terkait erat dengan kriminalitas transnasional dan dinyatakan sebagai pelanggaran hak asasi manusia serta merendahkan martabat bangsa dan negara serta merupakan kejahatan kemanusiaan karena memperlakukan orang sebagai komoditi yang dapat dibeli, dijual, dikirim dan dijual kembali. Faktor lain juga yang menyebabkan terjadinya perdagangan orang adalah faktor pendidikan dan keterbatasan informasi yang dimiliki sehingga menyebabkan perempuan terjebak dalam perdagangan orang. Perlindungan hukum terhadap tindak pidana perdagangan orang mulai berkembang sebagai suatu upaya untuk memberikan perlindungan oleh karena perempuan dan/atau anak banyak menjadi korban ketidakadilan, kekerasan dan lain sebagainya. Upaya demikian tumbuh dari kesadaran bahwa selama ini kehidupan perempuan/anak kurang mendapatkan perhatian karena alasan budaya, agama, ekonomi, sosial dan hukum dalam masyarakat seperti menguatnya pola.
\end{abstract}

Keywords: Hukum, Kebijakan, Korban, Tindak Pidana Perdagangan, Perlindungan.

\section{ABSTRACT}

At the world level, trafficking in persons is closely linked to transnational crime and is declared a violation of human rights and degrading the nation and state and is a crime against humanity because it treats people as a commodity that can be bought, sold, shipped and resold. Another factor that causes trafficking in persons is the factor of education and the limited information they have which causes women to be trapped in trafficking in persons. 
Legal protection against the criminal act of trafficking in persons has begun to develop as an effort to provide protection because many women and / or children have become victims of injustice, violence and so on. Such efforts grow from the awareness that so far the lives of women / children have received less attention due to cultural, religious, economic, social and legal reasons in society such as strengthening patterns.

Keywords: Law, Policy, Victims, Crime of Trafficking, Protection.

\section{PENDAHULUAN}

Tindak Pidana Perdagangan Orang merupakan bentuk perbuatan pelanggaran terhadap harkat dan martabat manusia. Karenanya bentuk perbuatan ini, selain melanggar hukum, juga melanggar Hak Asasi Manusia. Menurut Undang-Undang Dasar Negara Republik Indonesia Tahun 1945 menegaskan bahwa; segala warga negara bersamaan kedudukannya didalam hukum dan/atau pemerintahan dan wajib menjunjung hukum dan pemerintahan itu dengan tidak ada kecualinya (Pasal 27 ayat (1)). Dewasa ini di Indonesia perdagangan orang sangat marak dan mengkhawatirkan walaupun peraturan pemberantasan tindak pidana perdagangan orang sudah ada, yaitu Undang-undang Nomor 21 Tahun 2007, tetapi dalam praktiknya perbuatan tersebut masih banyak terjadi, bahkan bukan hanya melibatkan perorangan, tetapi juga melibatkan jaringan sindikat kerja yang sulit diketahui.

Kondisi seperti ini, antara lain mengakibatkan serta maraknya aktivitas Perdagangan Orang yang mendapat sorotan baik dalam negeri maupun luar negeri. Indonesia mendapat sorotan dunia Internasional mengingat keberadaannya sebagai salah satu negara sumber terjadinya aktivitas perdagangan manusia. Berdasarkan Annual Trafficking in Person Report dari US Departement of State kepada Kongress sebagaimana diamanatkan dalam The Trafficking Victims Protection Act of 2000, pada periode April 2001 s/d Maret 2002, Indonesia termasuk dalam kelompok negara dengan kategori terendah, yaitu negara yang sama sekali tidak memenuhi standar minimum dalam memerangi perdagangan manusia (Trafficking in person).

Hampir semua negara di dunia mengalami permasalahan perdagangan orang, dengan tingkat yang berbeda-beda. Ada negara yang menjadi negara tujuan perdagangan orang, negara transit atau negara sumber terjadinya perdagangan orang, seperti yang di alami Negara Indonesia. Maraknya isu perdagangan orang diawali dengan meningkatnya pencari kerja baik perempuan maupun laki-laki bahkan anak-anak untuk bermigrasi keluar daerah sampai keluar negeri. Beberapa faktor penyebab terjadinya perdagangan orang antara lain disebabkan ketidaktersedianya lapangan kerja, perubahan orientasi pembangunan dari pertanian ke industri serta krisis ekonomi. Perdagangan orang tidak hanya terjadi di Indonesia saja sebagai negara berkembang, melainkan juga dialami oleh negara berkembang lainnya seperti: Vietnam, Srilangka, Thailand dan Philipina.

Pada tingkat dunia, perdagangan orang terkait erat dengan kriminalitas transnasional dan dinyatakan sebagai pelanggaran hak asasi manusia serta merendahkan martabat bangsa dan negara serta merupakan kejahatan kemanusiaan karena memperlakukan orang sebagai komoditi yang dapat dibeli, dijual, dikirim dan dijual kembali. Faktor lain juga yang menyebabkan 
terjadinya perdagangan orang adalah faktor pendidikan dan keterbatasan informasi yang dimiliki sehingga menyebabkan perempuan terjebak dalam perdagangan orang.

Berdasarkan data dari Badan Reserse dan Kriminal Polri (bareskrim) Mabes Polri, pada tahun 2008 tercatat 199 kasus ditangani jajaran Reskrim se- Indonesia, dengan 291 pelaku Tindak Pidana Perdagangan Orang yang ditangkap dan 107 kasus di antaranya telah diseselesaikan di tingkat Kejaksaan. Dari 598 orang korban, 510 diantaranya orang dewasa, 88 orang lainnya adalah anak-anak. Dari beberapa kasus pada tahun 2008, korban umumnya menjadi korban eksploitasi seksual seperti pelacuran dan paedophilia, dengan rincian 90 kasus eksploitasi seksual dengan jumlah korban perempuan sebanyak 210 orang, dan korban anak-anak sebanyak 55 orang. Kasus yang ditangani secara hukum diatas hanyalah sebagian dari begitu banyak kasus yang secara pasti sulit diketahui. Kesulitan mengungkapkan kasus tindak pidana perdagangan orang, karena pada umumnya melibatkan jaringan yang sangat rapih, baik yang terorganisir maupun tidak terorganisir dan menjangkau dalam negeri sampai antar Negara.

Pada umumnya kasus tindak pidana perdagangan orang yang diproses aparat hukum, setelah ada pengaduan dari korban atau keluarga, dan pihak lain yang peduli dengan tindak pidana perdagangan orang. Dalam praktiknya, perempuan adalah kelompok yang paling rentan menjadi korban tindak pidana perdagangan orang. Sebagian besar korban perempuan yang diperdagangkan untuk tujuan pelacuran atau bentuk eksploitasi seksual lainnya, selebihnya berupa eksploitasi, seperti kerja paksa atau pelayanan paksa seperti praktek serupa perbudakan. Perdagangan orang merupakan perlakuan terburuk dari pelanggaran harkat dan martabat manusia. Perdagangan Orang juga merupakan bentuk modern dari perbudakan. Perbudakan adalah kondisi seseorang dibawah kepemilikan atau kekuasaan orang lain, sehingga tidak mampu menolak suatu pekerjaan secara melawan hukum yang diperintahkan oleh orang lain walaupun pekerjaan itu tidak dikehendakinya.

Upaya perlindungan hukum terhadap tindak pidana perdagangan orang yaitu salah satunya melalui pencegahan dan penegakan hukum untuk memberantas perdagangan orang. Tindakan ini perlu secara terus menerus dilakukan dengan diikuti berbagai upaya peningkatan sumber daya manusia yang berkualitas. Oleh karena setiap orang memiliki kedudukan yang sama di depan hukum (Equality before the law), maka Kualitas perlindungan terhadap perempuan hendaknya memiliki derajat atau tingkat yang sama dengan perlindungan dengan pria. Dalam sejarah perdagangan orang, awalnya yang menjadi obyek perdagangn orang adalah perempuan. Hal ini disebabkan dengan adanya pandangan merendahkan derajat perempuan yang berlangsung hingga abad pertengahan. Perempuan sebagai korban perdagangan orang oleh hukum dinyatakan sebagai suatu tindak pidana dan diancam pidana sebagaimana baik menurut ketentuan-ketentuan dalam Kitab Undang-Undang Hukum Pidana (KUHP) maupun peraturan tindak pidana diluar KUHP.

Pasal 297 KUHP misalnya adalah salah satu ketentuan yang mengancam pidana terhadap pelaku tindak pidana perdagangan perempuan. Diluar KUHP ditemukan pengaturannya dalam Pasal 83 Undang-Undang Nomor 23 Tahun 2002 tentang Perlindungan Anak, dan kemudian dalam Undang-Undang Nomor 21 Tahun 2007 tentang Pemberantasan Tindak Pidana 
Perdagangan Orang (Bab II dan bab III). Beberapa ketentuan hukum yang memberikan perlindungan hukum terhadap perempuan maupun sebagai korban tindak pidana juga diatur dalam berbagai ketentuan Hukum Nasional seperti dalam Undang-undang Nomor 39 Tahun 1999 tentang Hak Asasi Manusia (HAM), yakni bab III Bagian Kesembilan, Undang-undang Nomor 13 Tahun 2006 tentang Perlindungan Saksi dan Korban, Undang-undang Nomor 44 Tahun 2008 tentang Pornografi serta berbagai Konvensi Internasional.

Perlindungan hukum terhadap tindak pidana perdagangan orang mulai berkembang sebagai suatu upaya untuk memberikan perlindungan oleh karena perempuan dan/atau anak banyak menjadi korban ketidakadilan, kekerasan dan lain sebagainya. Upaya demikian tumbuh dari kesadaran bahwa selama ini kehidupan perempuan/anak kurang mendapatkan perhatian karena alasan budaya, agama, ekonomi, sosial dan hukum dalam masyarakat seperti menguatnya pola pikir bahwa perempuan merupakan makhluk lemah yang harus dilindungi oleh laki-laki.

Satjipto Rahardjo dalam Savitri mengemukakan bahwa: Dunia tidak pernah menyadari kalau sistem hukum memang berkelamin laki-laki, walaupun kesadaran tersebut hanya bisa dimunculkan bila orang bergerak dalam ranah sosiologi hukum. Sebaliknya, studi hukum positivistik, dogmatis, dan analitis justru tidak mampu membawa manusia ke kesadaran seperti itu . Kitab Undang-undang Hukum Pidana (KUHP) misalnya, banyak menekankan ketentuan yang memposisikan perempuan sebagai korban perdagangan orang (Pasal 297). Demikian pula dalam Undang-undang Nomor 21 Tahun 2007 tentang Pemberantasan Tindak Pidana Perdagangan Orang yang dalam penjelasan umumnya menjelaskan bahwa berdasarkan bukti empiris, perempuan dan anak adalah kelompok yang paling banyak menjadi korban tindak pidana perdagangan orang. Korban diperdagangkan tidak hanya untuk tujuan pelacuran atau bentuk eksploitasi seksual tetapi mencakup bentuk eksploitasi lain, misalnya kerja paksa atau pelayanan paksa, perbudakan, atau praktik serupa perbudakan itu.

Oleh karena itu segala bentuk perlakuan yang mengganggu dan merusak hak-hak dasarnya dalam berbagai bentuk pemanfaatan dan eksploitasi yang tak berprikemanusiaan harus segera dihentikan. Kesadaran untuk memberdayakan perempuan sekaligus untuk memberikan perlindungan muncul sebagai suatu upaya dan gerakan yang menuntut kesamaan dan keadilan gender, dan berpandangan bahwa sejumlah ketentuan hukum kurang memberikan perlindungan dan kesamaan kedudukan bagi perempuan, seperti dikemukakan oleh Danardono sebagai berikut: "Para penganut teori positivisme hukum menganggap hukum sebagai potret dari realitas sosial atau bahkan realitas itu sendiri, sehingga untuk mengetahui bentuk pembagian kerja secara seksual (pembagian kerja di masyarakat dan rumah tangga antara pria dan perempuan) yang pernah dan berlaku di Indonesia, seseorang dianggap cukup membaca, misalnya KUHPerdata, Undang-undang Perkawinan No.1 Tahun 1974 dan beberapa pasal dalam KUHP. Namun, berbeda dari para penganut teori positivisme hukum, para pemikir hukum feminis justru menganggap berbagai ketentuan hukum tersebut memarginalkan perempuan".

Ketidakadilan gender sebenarnya telah lama diperjuangkan para tokoh gerakan perempuan di Indonesia seperti: R.A.Kartini, Martha Christina Tiahahu, Cut Meutia, dan lain-lain, yang menurut Suryochondro, ternyata timbulnya gerakan wanita adalah kesadaran untuk mencari 
keadilan bagi wanita. Bangkitnya kesadaran perempuan digambarkan oleh Pembayun dalam pemikiran sebagai bentuk tanggung jawab sosial perempuan (Woman Social Responsibility/WSR) bahwa, tumbuhnya kesadaran karena negara telah gagal dalam menghapus sub-ordinasi perempuan dan anak-anak serta gagal memenuhi janji pemberdayaan perempuan secara tuntas dan merata. WSR ini memiliki tiga prinsip utama yang berbeda, tetapi integral, sebagai berikut: Pertama, bahwa kesadaran dan kecerdasan sosial (social intelligence) merupakan fitrah individu; Kedua, prinsip mengenali diri sendiri; Ketiga, prinsip tanggung jawab sosial (social responsibility) perempuan terhadap kaum perempuan lain dan anak-anak.

Uraian yang dilatar belakangi oleh ketidakadilan (hukum) terhadap perempuan dan berbagai gerakan untuk memperjuangkan keadilan dan kesetaraan gender tersebut, dihadapkan pada berbagai kendala jika di tinjau dari aspek hukum mengingat menguatnya Positivisme Hukum di Indonesia. Positivisme hukum atau juga dinamakan sebagai aliran legisme, sangat mengagungkan hukum tertulis sehingga aliran ini beranggapan tidak ada norma hukum diluar hukum positif. Hukum positif seperti KUHP, KUHPerdata, Undang-undang Nomor 21 Tahun 2007 tentang Pemberantasan Tindak Pidana Perdagangan Orang adalah ketentuan hukum yang berlaku dengan karakteristiknya bersifat tertulis.

Astawa dan $\mathrm{Na}^{\text {'a }}$ merumuskan peraturan perundang-undangan sebagai setiap keputusan tertulis yang dibentuk, ditetapkan dan dikeluarkan oleh lembaga atau pejabat yang berwenang dan berisi norma yang bersifat mengikat secara umum serta dapat menimbulkan konsekuensi bahwa hukum positif di suatu waktu akan ketinggalan zaman, dan tidak memenuhi kebutuhan hukum dalam masyarakat. KUHP misalnya telah mengatur perdagangan perempuan dan anak sebagai tindak pidana, akan tetapi dirasa kurang memberikan suatu kekuatan hukum seperti rendahnya ancaman pidananya, sehingga di perlukan ketentuan hukum baru yang terjelma dalam Undang-undang Nomor 21 Tahun 2007 tentang Pemberantasan Tindak Pidana Perdagangan Orang, Pasal 83 Undang-undang Nomor 23 Tahun 2002 tentang Perlindungan Anak, menentukan larangan, memperdagangkan, menjual, atau menculik anak untuk diri sendiri atau untuk dijual.

Namun ketentuan KUHP dan Undang-undang Perlindungan Anak tersebut tidak merumuskan apa yang dimaksud dengan perdagangan. Di samping itu Pasal 297 KUHP memberikan sanksi yang terlalu ringan dan tidak sepadan dengan dampak yang diderita korban akibat kejahatan perdagangan orang. Menurut Abdul Wahid dan Muhammad Irfan, dikemukakannya bahwa: Kekerasan, pelecehan, dan eksploitasi seksual itu bahkan bukan hanya menimpa perempuan dewasa, namun juga perempuan yang tergolong dibawa umur (anak-anak). Kejahatan seksual ini juga tidak hanya berlangsung dilingkungan perusahaan, perkantoran atau ditempat-tempat tertentu yang memberikan peluang manusia berlainan jenis dapat saling berkomunikasi, namun juga dapat terjadi dilingkungan keluarga.

Kekerasan terhadap perempuan seperti pemaksaan eksploitasi seksual, menurut Savitri, pada dasarnya adalah kekerasan gender, yakni kekerasan yang memberikan penekanan khusus pada akar permasalahan kekerasan yang dilakukan terhadap perempuan, yaitu diantara pelaku dan korbannya terdapat relasi gender dalam hal mana posisi dan perannya tersebut pelaku 
mengendalikan dan korban adalah orang yang dikendalikan melalui tindakan kekerasan tersebut. Perdagangan perempuan untuk kepentingan pelacuran adalah bentuk kekerasan berbasis gender dan merupakan kejahatan, namun pihak pengguna (jasa) pelacuran ternyata tidak terjamah oleh ketentuan hukum yang berlaku. Pengguna jasa perdagangan perempuan dalam kegiatan pelacuran tentunya ada laki-laki.

Undang-undang Nomor 21 Tahun 2007 tentang Pemberantasan Tindak Pidana Perdagangan Orang tidak mengatur ketentuan pidana untuk menjaringnya sebagai pelaku (pengguna jasa). Sebagai korban perdagangan orang, perempuan membutuhkan perhatian baik perlindungannya sebagai korban maupun sebagai saksi korban. Tidak jarang, karena alasan malu agar tidak diketahui umum, korban menutup diri dari upaya proses hukum oleh aparat penegak hukum. Kondisi demikian lebih mempersulit upaya penegakan hukumnya, walaupun saksi dan korban perdagangan orang telah dijamin perlindungan hukumnya baik oleh Undang-undang Nomor 21 Tahun 2007 (Bab V) tentang Pemberantasan Tindak Pidana Perdagangan Orang maupun oleh Undang-undang Nomor 13 Tahun 2006 tentang Perlindungan Saksi dan Korban. Korban perdagangan perempuan dapat terjerumus ke lingkungan yang tidak baik dan tidak sehat, misalnya karena merasa telah ternoda atau tercemar, akan malu kembali kepada orang tua dan akhirnya menerjuni profesi selaku pelacur dengan kehendak sendiri.

Perlindungan terhadap korban juga tidak lepas dari peran pemuka masyarakat, pemuka agama, psikolog, pemerintah pusat maupun pemerintah daerah, dan tidak kalah penting artinya ialah peran aparat penegak hukum. Sebagai negara hukum dan menjunjung tinggi HAM, penguatan hukum dan HAM menjadi momentum penting dalam pemberantasan tindak pidana perdagangan orang. Asshiddiqie mengemukakan, munculnya gelombang besar di bidang politik yang dapat dilihat dari berkembangnya isu demokratisasi, HAM, dan Lingkungan hidup adalah bagian penting untuk menjadikan hukum dan HAM sebagai kekuatan utama dalam pemberantasan perdagangan perempuan di Indonesia.

Upaya perlindungan hukum terhadap perempuan, merupakan hal yang sangat penting, salah satunya melalui pencegahan dan pemberantasan perdagangan orang, perlu secara terus menerus dilakukan demi tetap terpeliharanya sumber daya manusia yang berkualitas. Kualitas perlindungan terhadap perempuan hendaknya memiliki derajat/tingkat yang sama dengan perlindungan terhadap kaum pria, karena setiap orang memiliki kedudukan yang sama di depan hukum (equality before the law). Salah satu bentuk kejahatan dimana perempuan sebagai objeknya, yang terkait erat dengan kejahatan perdagangan orang, ialah maraknya kemajuan teknologi informasi dalam bentuk kejahatan dunia maya (cyber crimes) seperti melalui penggunaan beberapa perangkatnya, misalnya handphone (HP), internet, yang jenis-jenis kejahatan ini menurut Dikdik M. Arief Mensur dan Elisatris Gultom, disebutkan diantaranya:

1. Cyber-terrorist: National Police Agency of Japan (NPA) mendefinisikan Cyber Terrorist sebagai electronic attacks through computer networks against critical infrastruktures that have potential critical effects in social and economic activities of the nation. Penjelasan maksud dan tujuannya adalah Cyber-terrorist: National Police Agency of Japan (NPA) mendefinisikan Cyber Terrorist sebagai serangan elektronik 
melalui jaringan komputer terhadap infrastruktur kritis yang berpotensi menimbulkan efek kritis dalam kegiatan sosial dan ekonomi bangsa.

2. Cyber-pornography: penyebarluasan obscene materials termasuk pornography, indecent exposure, dan child pornography

3. Cyber-harassment: pelecehan seksual melalui e-mail, website atau chat programs

4. Cyber-stalking: crimes of stalking melalui penggunaan komputer dan internet

5. Hacking: penggunaan programming abilities dengan maksud yang bertentangan dengan hukum

6. Carding (credit card fraud): melibatkan berbagai macam aktivitas dengan kartu kredit.

Perempuan sebagai objek pornografi merupakan bagian dari kekerasan dan tindakan yang merendahkan perempuan itu sendiri. Menurut Mackinnon dalam Situmorang, disebutkan bahwa: Pornografi menyebabkan perilaku kekerasan dan diskriminasi terhadap perempuan, baik perempuan yang menjadi objek dalam produkproduk pornografi maupun perempuan di kehidupan nyata. Ini berarti perempuan mengalami kekerasan ganda karena mereka selalu menjadi objek seks.

Perempuan sebagai objek sekaligus korban dalam kegiatan pornografi, senantiasa terkait dengan perempuan sebagai korban perdagangan orang mengingat pornografi pada dasarnya adalah bentuk ekspoloitasi (tubuh) perempuan. Kegiatan pornografi sudah tentu tidak lepas dari berbagai faktor sekaligus motif tertentu sebagaimana halnya faktor dan motif timbulnya perdagangan perempuan. Sagala mengemukakan penyebabnya seperti pernikahan dini dan lain sebagainya, bahwa: Kemiskinan di pedesaan, pernikahan dini, pendidikan yang minim, kondisi kesehatan yang memprihatinkan, pada kenyataannya mendorong remaja dan perempuan muda terjerembab kedalam prostitusi atau menjadi korban perdagangan (trafficking) perempuan.

Beberapa peraturan perundang-undangan yang mengatur dan mengancam tindak pidana perdagangan orang, kekerasan terhadap perempuan dan anak, serta kejahatan pornografi tersebut, membutuhkan upaya hukum secara nyata dalam implementasinya. Ketika para aktivis yang sebelumnya telah memperjuangkan agar ada perangkat hukum yang memberikan perlindungan hukum terhadap perempuan korban perdagangan orang seperti disebutkan di atas, ternyata yang menjadi masalah berada pada tataran penegakan hukum. Apalagi, Undang-undang Nomor 21 Tahun 2007 tentang Pemberantasan Tindak Pidana Perdagangan Orang mengamanatkan tindakan pencegahan dan penanganan kasus perdagangan orang pada pemerintah pusat maupun pemerintah daerah (Pasal 57) dengan memberikan peluang bagi pemerintah daerah membuat dan memberlakukan Peraturan Daerah (Perda) anti-Trafficking.

Meskipun Sumatera Barat diindikasikan belum terlalu tersentuh oleh dampak perdagangan orang (human trafficking) dan budaya minang adat basandi syarak, syarak basandi kitabullah serta falsafah hidup orang minang yang masih dipegang sampai sekarang yakni anak dipangku kamanakan dibimbiang, urang kampuang dipatenggangkan diyakini mampu mencegah terjadi human trafficking. Sebab falsafah dan budaya Minang tersebut bermakna kontrol masyarakat yang cukup tinggi dalam aktivitas kehidupan orang Minang. 
Selaras dengan itu ada ungkapan lain yang menggambarkan tata cara orang Minang dalam bersikap dan bertingkah laku di masyarakat yang dikenal dengan "kato nan ampek" atau biasa juga disebut dengan jalan nan ampek sudah menjadi ciri khas pergaulan masyarakat Minang dari nenek moyang sampai pada saat sekarang ini. Orang minang yang salah berperilaku atau menempatkan posisinya disebut dengan indak tau jo nan ampek atau urang indak baradaik. Ungkapan adat tersebut: nan tuo di hormati, nan ketek di sayangi, samo gadang baok baiyo. Tingginya kasus human trafficking di Indonesia menurut Kementerian Negara Pemberdayaan Perempuan salah satu faktornya dikarenakan belum adanya peraturan/undang-undang yang khusus mengenai human trafficking di Indonesia. Seperti halnya Sumatera Barat meskipun belum ada Perda tentang human trafficking, namun Kearifan lokal dan nilai serta norma yang secara langsung maupun tidak falsafah hidup dan budaya Minang mempunyai kaitan yang sangat kuat dalam mendorong atau tidak mendorong terjadinya human trafficking di Sumatera Barat. Bertitik tolak dari fenomena di atas penulis tertarik melakukan penelitian mengenai kebijakan kearifan lokal minang dalam upaya pencegahan human trafficking, dengan fokus kajian pada faktor pendorong dan faktor penarik terjadinya human trafficking.

Meskipun demikian Sumatera Barat telah memiliki Peraturan Daerah Provinsi Sumatera Barat Nomor 5 Tahun 2013 tentang Perlindungan Perempuan dan Anak yangmana dalam Perda tersebut telah mengatur tentang Perlindungan Perempuan dan Anak yang ada pada Pasal 1 angka (6) dan Pasal 1 angka (7) yang berbunyi:

\section{Pasal 1 angka (6);}

"Perlindungan Perempuan adalah segala upaya untuk menjamin dan melindungi hak-hak perempuan agar dapat hidup sehat dan berpartisipasi secara optimal sesuai dengan harkat dan martabat kemanusiaan serta mendapat perlindungan dari keterlantaran, kekerasan dan diskriminasi, baik berupa perlindungan preventif, represif maupun postremedial (pendampingan dan pengobatan)."

\section{Pasal 1 angka (7);}

"Perlindungan anak adalah segala kegiatan untuk menjamin dan melindungi anak dan hak haknya agar dapat hidup, tumbuh, berkembang, dan berpartisipasi, secara optimal sesuai dengan harkat dan martabat kemanusiaan, serta mendapat perlindungan dari kekerasan dan diskriminasi."

Serta telah dijelaskan juga pada Pasal 1 angka (15) yangmana dalam pasal tersebut berbunyi:

"Perdagangan orang adalah tindakan perekrutan, pengangkutan, penampungan, pengiriman, pemindahan, atau penerimaan seseorang dengan ancaman kekerasan, penggunaan kekerasan, penculikan, penyekapan, pemalsuan, penipuan, penyalahgunaan kekuasaan atau posisi rentan, penjeratan utang atau memberi bayaran atau manfaat, sehingga memperoleh persetujuan dari orang yang memegang kendali atas orang lain tersebut, baik yang dilakukan di dalam Negara maupun antar Negara, untuk tujuan eksploitasi atau mengakibatkan orang tereksploitasi”. 
Sedangkan dalam Undang-Undang Nomor 39 Tahun 1999 Tentang Hak Asasi Manusia pada Pasal 1, Pasal 3, Pasal 4, Pasal 20, Pasal 71 dan Pasal 72 yang berbunyi sebagai berikut:

\section{Pasal 1:}

"Setiap orang dilahirkan bebas dengan harkat dan martabat manusia yang sama dan sederajat serta dikaruniai akal dan hati nurani untuk hidup bermasyarakat, berbangsa, dan bernegara dalam semangat persaudaraan. Setiap orang berhak atas pengakuan, jaminan, perlindungan dan perlakuan hukum yang adil serta mendapat kepastian hukum dan perlakuan yang sama di depan hukum".

\section{Pasal 3:}

"Setiap orang berhak atas perlindungan hak asasi manusia dan kebebasan dasar manusia, tanpa diskriminasi”".

\section{Pasal 4:}

"Hak untuk hidup, hak untuk tidak disiksa, hak kebebasan pribadi, pikiran dan hati nurani, hak beragama, hak untuk tidak diperbudak, hak untuk diakui sebagai pribadi dan persamaan di hadapan hukum, dan hak untuk tidak dituntut atas dasar hukum yang berlaku surut adalah hak asasi manusia yang tidak dapat dikurangi dalam keadaan apa pun dan oleh siapa pun".

\section{Pasal 20:}

"Tidak seorang pun boleh diperbudak atau diperhamba. Perbudakan atau perhambaan, pedagangan budak, perdagangan wanita, dan segala perbuatan berupa apapun yang tujuannya serupa, dilarang".

\section{Pasal 71 dan Pasal 72:}

"Pemerintah wajib dan bertanggung jawab menghormati, melindungi, menegakkan, dan memajukan hak asasi manusia yang diatur dalam undang-undang ini, peraturan perundangan lain, dan hukum internasional tentang hak asasi manusia yang diterima oleh negara Republik Indonesia. Kewajiban dan tanggung jawab Pemerintah tersebut meliputi langkah implementasi yang efektif dalam bidang hukum, politik, ekonomi, sosial, budaya, pertahanan keamanan negara, dan bidang lain”.

Dari beberapa pasal diatas, Undang-Undang Republik Indonesia Nomor 39 Tahun 1999 Tentang Hak Asasi Manusia, maka dapat kita lihat bahwa setiap manusia hendaklah menghormati hak asasi manusia yang lain, tidak boleh melakukan diskriminasi terhadap sesama manusia apalagi perbuatan yang terkategori sebagai tindak pidana. Semakin berkembangnya zaman maka semakin banyak pula tindak pidana yang terjadi.

\section{METODE PENELITIAN}

Spesifikasi Penelitan yang digunakan dalam penelitian ini adalah deskriptif analitis, yaitu penelitian yang menggambarkan sekaligus melakukan analisis mengenai perlindungan hukum terhadap korban tindak pidana perdagangan orang: studi atas kelembagaan, ruang lingkup dan kebijakan. Pendekatan yang digunakan dalam penelitian ini adalah pendekatan yuridis normatif. Pendekatan yuridis normatif didukung empiris yang dilakukan menitiberatkan pada data 
kepustakaan dengan menginventarisasikan bahan-bahan kepustakaan mengenai perlindungan hukum terhadap korban tindak pidana perdagangan orang: studi atas kelembagaan, ruang lingkup dan kebijakan.

\section{HASIL DAN PEMBAHASAN}

\section{Hak Asasi Manusia}

Pada akhir abad XIV hingga awal abad XIIV John Locke mencetus kan ide tentang Hak asasi manusia yang mana hak asasi manusia ini adalah hak yang di bawa semenjak lahir yang melekat pada setiap manusia dan tidak dapat diganggu gugat ataupun dihilangkan. Hal ini yang menjadi ide dasar munculnya gerakan pembelaan hak asasi manusia di dunia barat. Dan muncul juga ide dari J.J Rousseau yang menyatakan bahwa Negara tidak bisa mencabut hak-hak dasar yang dimiliki individu dan masyarakat, melainkan Negara harus melindungi hak-hak tersebut.

Secara etimologis hak asasi manusia terdiri dari tiga kata yakni: hak, asasi, dan manusia. Hak dan asasi berasal dari bahasa Arab, yaitu haqq yang di ambil dari kata haqqa, yahiqqu, haqqaan yang artinya adalah benar, nyata, pasti, tetap, dan wajib. Makaa haqq adalah kewenangan atau kewajiban untuk melakukan sesuatu atau tidak melakukan sesuatu. Kata asasiy yang di ambil dari kata assa, yaussu, asasaan yang artinya membangun, mendirikan, meletekkan. Maka asasi adalah segala sesuatu yang bersifat mendasar dan fundamental yang selalu melekat pada objeknya sedangkan kata manusia berasal dari Bahasa Indonesia. Jadi di Indonesia HAM diartikan sebagai hak-hak mendasar pada Manusia.

Pengertian HAM di atas di Indonesia masih sangat umum dan universal, tetapi Indonesia juga memiliki konsep tentang HAM yang di atur secara jelas dalam Pasal 1 angka (1) Undangundang Nomor 39 Tahun 1999 tentang Hak Asasi Manusia yang menyebutkan tentang pengertian hak asasi manusia, yaitu "Hak asasi manusia adalah seperangkat hak yang melekat padahakekat dan keberadaan manusia sebagai mahluk Tuhan Yang Maha Esa, dan merupakan anugerahnya yang wajib dihormati, dijunjung tinggi, dan dilindungi oleh negara, hukum dan pemerintah, dan setiap orang demi kehormatan serta perlindungan harkat dan martabat manusia".

Berdasarkan pengertian HAM dari undang-undang tersebut dapat dikatakan bahwa penting dan adanya suatu kewajiban setiap orang untuk menghormati hak-hak individu yang dimiliki setiap orang. Kewajiban tersebut telah dituangkan dalam undang-undang sebagai seperangkat kewajiban sehingga apabila tidak dilaksanakan maka tidak akan terlaksana dan tegaknya perlindungan terhadap hak asasi manusia.

\section{Perlindungan Hukum}

Dalam Kamus Besar Bahasa Indonesia, Perlindungan berasal dari kata lindung yang memiliki arti mengayomi, mencegah, mempertahankan, dan membentengi. Sedangkan Perlindungan berarti konservasi, pemeliharaan, penjagaan, asilun, dan bunker. Secara umum, perlindungan berarti mengayomi sesuatu dari hal-hal yang berbahaya, sesuatu itu bisa saja berupa kepentingan maupun benda atau barang. Selain itu perlindungan juga mengandung makna 
pengayoman yang diberikan oleh seseorang terhadap orang yang lebih lemah. Dengan demikian, perlindungan hukum dapat diartikan Perlidungan oleh hukum atau perlindungan dengan menggunakan pranata dan sarana hukum.

Namun dalam hukum Pengertian perlindungan hukum adalah Segala daya upaya yang di lakukan secara sadar oleh setiap orang maupun lembaga pemerintah, swasta yang bertujuan mengusahakan pengamanan, penguasaan dan pemenuhan kesehjahteraan hidup sesuai dengan hak-hak asasi yang ada sebagaimana di atur dalam Undang-undang Nomor 39 Tahun 1999 tentang Hak Asasi Manusia. Dengan kata lain perlindungan hukum sebagai suatu gambaran dari fungsi hukum, yaitu konsep dimana hukum dapat memberikan suatu keadilan, ketertiban, kepastian, kemanfaatan dan kedamaian.

Pada dasarnya perlindungan hukum tidak membedakan terhadap kaum pria maupun wanita. Indonesia sebagai negara hukum berdasarkan pancasila haruslah memberikan perlindungan hukum terhadap warga masyarakatnya karena itu perlindungan hukum tersebut akan melahirkan pengakuan dan perlindungan hak asasi manusia dalam wujudnya sebagai makhluk individu dan makhluk sosial dalam wadah negara kesatuan yang menjunjung tinggi semangat kekeluargaan demi mencapai kesejahteraan bersama.

\section{Sistem Peradilan Pidana}

Menurut Mardjono Reksodiputro, Sistem peradilan pidana adalah sistem pengendalian kejahatan yang terdiri dari lembaga-lembaga kepolisian. Kejaksaan, pengadilan dan permasyarakatan terpidana. Dikemukakan pula bahwa sistem peradilan pidana (criminal justice system) adalah sistem dalam suatu masyarakat untuk menanggulangi kejahatan. Menanggulangi diartikan sebagai mengendalikan kejahatan agar berada dalam batas-batas toleransi masyarakat. Pengendalian kejahatan agar masih dalam batas toleransi masyarakat tidak berarti memberikan toleransi terhadap suatu tindak kejahatan tertentu atau membiarkannya untuk terjadi. Toleransi tersebut sebagai suatu kesadaran bahwa kejahatan akan tetap ada selama masih ada manusia di dalam masyarakat. Jadi, dimana ada masyarakat pasti tetap akan ada kejahatan.

Menurut Muladi, Sistem peradilan pidana merupakan suatu jaringan (network) peradilan yang menggunakan hukum pidana sebagai sarana utamanya, baik hukum pidana materiil, hukum pidana formil maupun hukum pelaksnaan pidana. Namun demikian kelembagaan substansial ini harus dilihat dalam kerangka atau konteks sosial. Sifatnya yang terlalu formal apabila dilandasi hanya untuk kepentingan kepastian hukum saja akan membawa kepada ketidakadilan.

Mengartikan sistem peradilan pidana sebagai pemakaian pendekatan sistem terhadap mekanisme administrasi peradilan pidana dan peradilan pidana sebagai suatu sistem merupakan hasil interaksi antara peraturan perundang-undangan, praktik administrasi dan sikap atau tingkah laku sosial.

Sistem peradilan pidana di Indonesia terdiri dari hukum pidana materiil dan hukum pidana formal. Sistem peradilan pidana Indonesia menganut konsep bahwa perkara pidana adalah sengketa antara individu dan masyarakat (publik) dan akan diselesaikan oleh negara sebagai perwakilan dari publik. Sengketa itu sendiri adalah berhubungan dengan beberapa substansi dari 
pasal yang sudah diatur dan diancam dengan hukuman dalam hukum pidana materiil, yang saat ini ditentukan dalam KUHP dan di luar.

Dalam menyelenggarakan sistem peradilan pidana tersebut, Indonesia memiliki Undangundang Nomor 8 Tahun 1981 tentang Kitab Undang-Undang Hukum Acara Pidana (KUHAP). Ditegaskan dalam Pasal 2 KUHAP bahwa KUHAP berlaku untuk melaksanakan tata cara peradilan dalam lingkungan peradilan umum. KUHAP sebagai hukum acara pidana juga berisi ketentuan mengenai proses penyelesaian perkara pidana sekaligus menjamin hak asasi tersangka atau terdakwa. Hal ini terdapat pada penjelasan bahwa KUHAP sebagai hukum acara pidana yang berisi ketentuan tata tertib proses penyelesaian penanganan kasus tindak pidana, sekaligus telah memberi "legalisasi hak asasi" kepada tersangka atau terdakwa untuk membela kepentingannya di depan pemeriksaan aparat penegak hukum.

Pengakuan hukum yang tegas akan hak asasi yang melekat pada diri mereka dari tindakan sewenang-wenang. KUHAP telah mencoba menggariskan tata tertib hukum yang antara lain akan melepaskan tersangka atau terdakwa maupun keluarganya dari kesengsaraan putus asa di belantara penegakan hukum yang tak bertepi, karena sesuai dengan jiwa dan semangat yang diamanatkannya, tersangka atau terdakwa harus diperlakukan berdasarkan nilai-nilai yang manusiawi.

KUHAP, sebagaimana ditemukan dalam bagian penjelasan umum, setidaknya mengenal 10 (sepuluh) asas yang menjadi acuan kebenaran atau ajaran dari kaidah-kaidahnya, yaitu:

a. Asas Equality Before The Law

Perlakuan yang sama atas diri setiap orang di muka hukum dengan tidak mengadakan pembedaan perlakuan.

b. Asas Legalitas Dalam Upaya Paksa

Penangkapan, penahanan, penggeledahan, dan penyitaan hanya dilakukan berdasarkan perintah tertentu oleh pejabat yang diberi wewenang oleh undang-undang dan hanya dalam hal dan dengan cara yang diatur undang-undang.

\section{b. Asas Presumption Of Innocence}

Kepada seorang yang ditangkap, dituntut dan/atau dihadapkan di pengadilan wajib dianggap tidak bersalah sampai adanya putusan pengadilan yang menyatakan kesalahannya dan memperoleh kekuatan hukum tetap

c. Asas Remedy And Rehabilitation

Kepada seorang yang ditangkap, ditahan, dituntut ataupun diadili tanpa alasan yang berdasarkan undang-undang dan/atau karena kekeliruan mengenai orangnya atau hukum yang diterapkan wajib diberi ganti kerugian dan rehabilitasi sejak tingkat penyelidikan.

d. Asas Fair Impersonal And Objective

Peradilan harus dilakukan dengan cepat, sederhana, dan biaya ringan serta bebas, jujur, dan tidak memihak harus diterapkan secara konsekuen dalam seluruh tingkat peradilan.

e. Asas Legal Assistance

Setiap orang yang berperkara wajib diberi kesempatan untuk memperoleh bantuan hukum yang semata-mata diberikan untuk melaksanakan kepentingan pembelaan atas 
dirinya.

\section{f. Miranda Rule}

Kepada seorang tersangka, sejak saat dilakukan penangkapan dan penahanan selain wajib diberitahu dakwaan dan dasar hukum apa yang didakwakan kepadanya, juga wajib diberitahu haknya, termasuk hak untuk menghubungi dan minta bantuan penasihat hukum

g. Asas Presentasi

Pengadilan memeriksa perkara pidana dengan hadirnya terdakwa, kecuali dimungkinkan pemeriksaan tanpa hadirnya terdakwa (in absentia).

h. Asas Keterbukaan

Sidang pemeriksaan pengadilan adalah terbuka untuk umum, kecuali dalam hal yang diatur dalam undang-undang.

i. Asas Pengawasan

Pengawasan pelaksanaan putusan pengadilan dalam perkara pidana dilakukan oleh ketua pengadilan negeri yang bersangkutan.

\section{KESIMPULAN}

Pada tingkat dunia, perdagangan orang terkait erat dengan kriminalitas transnasional dan dinyatakan sebagai pelanggaran hak asasi manusia serta merendahkan martabat bangsa dan negara serta merupakan kejahatan kemanusiaan karena memperlakukan orang sebagai komoditi yang dapat dibeli, dijual, dikirim dan dijual kembali. Faktor lain juga yang menyebabkan terjadinya perdagangan orang adalah faktor pendidikan dan keterbatasan informasi yang dimiliki sehingga menyebabkan perempuan terjebak dalam perdagangan orang. Perlindungan hukum terhadap tindak pidana perdagangan orang mulai berkembang sebagai suatu upaya untuk memberikan perlindungan oleh karena perempuan dan/atau anak banyak menjadi korban ketidakadilan, kekerasan dan lain sebagainya. Upaya demikian tumbuh dari kesadaran bahwa selama ini kehidupan perempuan/anak kurang mendapatkan perhatian karena alasan budaya, agama, ekonomi, sosial dan hukum dalam masyarakat seperti menguatnya pola pikir bahwa perempuan merupakan makhluk lemah yang harus dilindungi oleh laki-laki.

\section{REFERENSI}

Abdul Wahid dan Muhammad Irfan, Perlindungan Hukum terhadap Korban Kekerasan Seksual (Advokasi atas Hak Asasi Perempuan), Refika Aditama, Bandung, 2001.

Ahmad Erani Yustika et al, Proyeksi Ekonomi 2014: Akankah Krisis Berlanjut?, INDEF, Jakarta, 2013.

D. Danardono, Teori Hukum Feminis; Menolak Netralitas Hukum, Merayakan Difference dan Anti- Essesialisme, dalam Silistyowati Irinato (ed), Perempuan dan Hukum, Yayasan Obor Indonesia, Jakarta, 2006. 
Dikdik M. Arief Mensur dan Elisatris Gultom, Cyber Law. Aspek Hukum Teknologi Informasi, Refika Aditama, Bandung, 2005.

Ellys Lestari Pembayun, Perempuan Vs Perempuan. Realitas Gender, Tayangan Gosip, dan Dunia Maya, Nuansa, Bandung, 2009.

Henny Nuraeny, Tindak Pidana Perdagangan Orang, Sinar Grafika, Jakarta, 2011.

I.G.P Astawa dan Suprin Na'a, Dinamika Hukum dan Ilmu Perundang-Undangan di Indonesia, Alumni, Bandung, 2008.

IOM Indonesia, Fenomena Trafiking Manusia dan Konteks Hukum Internasional, Jakarta, 2006.

Jimly Asshiddiqie, Agenda Pembangunan Hukum di Abad Globalisasi, Balai Pustaka, Jakarta, 1998.

M. Yahya Harahap, Pembahasan Permasalahan dan Penerapan KUHAP: Penyidikan dan Penuntutan. Sinar Grafka, Jakarta. 2014.

Mahrus Ali dan Syarif Nurhidayat, Penyelesaian Pelanggaran HAM Berat, Gramata Publishing, Jakarta, 2011.

Mardjono Reksodiputro, Sistem Peradilan Pidana Indonesia (Melihat Kepada Kejahatan dan Penegakan Hukum dalam Batas-Batas Toleransi), Fakultas Hukum Unversitas Indonesia, Jakarta, 1993.

Moeljatno, Asas-asas Hukum Pidana. Bina Aksara, Jakarta, 1987.

Muladi, Kapita Selekta Sistem Peradilan Pidana, Badan Penerbit Universitas Diponegoro, Semarang, 1995.

Niken Savitri, HAM Perempuan, Kritik Teori Hukum Feminis Terhadap KUHP, Refika Aditama, Bandung, 2008.

Noeng Muhadjir, Ilmu pendidikan dan Perubahan Sosial. Teori Pendidikan Pelaku Sosial Kreatif. Raka Sarasin, Yogyakarta, 2000.

Pangaribuan, Hukum Acara Pidana: Surat Resmi Advokat di Pengadilan. Papas Sinar Sinanti, Jakarta, 2014.

Ridwan Syahrani, Rangkuman Intisari Ilmu Hukum, Citra Aditya Bakti, Bandung, 2004.

Romli Atmasasmita, Sistem Peradilan Pidana (Criminal Justice System) Perspektif Eksistensialisme Dan Abolisionalisme, Penerbit Bina Cipta, Jakarta, 1996. 
Satjipro Rahardjo, Sisi-Sisi Lain dari Hukum di Indonesia, Kompas, Jakarta, 2003.

Sukanti Suryochondro, Timbulnya dan Perkembangan Gerakan Wanita di Indonesia, dalam T.O. Ihromi (ed), Kajian Wanita dalam pembangunan, Yayasan Obor Indonesia, Jakarta, 1996.

Sulistyowati Irianto, Perempuan dan Hukum, Yayasan Obor Indonesia, Jakarta, 2006.

Tim Penyusun Kamus Pusat Pembinaan dan Pengembangan Bahasa, Kamus Besar Bahasa Indonesia, Edisi kedua, cet. 1, Balai Pustaka, Jakarta, 1991.

Undang-Undang Dasar Negara Republik Indonesia Tahun 1945;

Undang-undang Nomor 1 Tahun 1946 tentang Peraturan Hukum Pidana (KUHP);

Undang-undang Nomor 8 Tahun 1981 tentang Hukum Acara Pidana (KUHAP);

Undang-undang Nomor 39 Tahun 1999 tentang Hak Asasi Manusia;

Undang-undang Nomor 21 Tahun 2007 tentang Pemberantasan Tindak Pidana Perdagangan Orang;

Undang-undang Nomor 12 Tahun 2017 tentang Pengesahan Asean Convention Against Trafficking In Persons, Especially Women And Children (Konvensi Asean Menentang Perdagangan Orang, Terutama Perempuan Dan Anak).

Peraturan Presiden Nomor 69 Tahun 2008 tentang Gugus Tugas Pencegahan dan Penanganan Tindak Pidana Perdagangan Orang yang diketuai oleh Menteri Negara Koordinator Bidang Kesejahteraan Rakyat

Peraturan Pemerintah Nomor 9 Tahun 2008 tentang Tata Cara dan Mekanisme Pelayanan Terpadu Bagi Saksi dan/atau Korban Tindak Pidana Perdagangan Orang;

Peraturan Pemerintah Nomor 58 Tahun 2010 Perubahan Atas Peraturan Pemerintah Nomor 27 Tahun 1983 tentang Pelaksanaan Kitab Undang-Undang Hukum Acara Pidana;

Peraturan Menteri Negara Pemberdayaan Perempuan dan Perlindungan Anak Republik Indonesia Nomor 22 Tahun 2010 tentang Prosedur Standar Operasional Pelayanan Terpadu Bagi Saksi dan/atau Korban Tindak Pidana Perdagangan Orang

Zainuddin, Metode Penelitian Hukum, Sinar Grafika Jakarta, 2009. 